\title{
The Dilemma and Countermeasures of Human Capital and Social Capital in College Students' Entrepreneurship
}

\author{
Yaoyao Yang \\ East China University of Science and Technology \\ Shandong Linyi \\ Organization and human resource management \\ yangyyqsd@sina.com
}

\begin{abstract}
The rising tide of entrepreneurship and the difficulty of employment of college graduates are becoming more and more prominent. Many college graduates choose to become self-employed. Human capital and social capital play an important role in the process of entrepreneurship. Due to the particularity of college students, they lack the accumulation of human capital and social capital. First of all, the role of human capital and social capital in entrepreneurship are pointed out in this paper, the understanding of the importance of human capital and social capital is strengthened. Secondly, the dilemma of college graduates to obtain human capital and social capital is analyzed. Finally, the countermeasures of obtaining human capital and social capital for college students in the new situation are put forward.
\end{abstract}

Keywords-entrepreneurship; human capital; social capital; college students entrepreneurs

\section{INTRODUCTION}

The employment problem of college graduates is becoming increasingly prominent. According to statistics, the number of graduating students in universities will reach 7 million 700 thousand in 2016, and the number of graduates will reached a record high. The employment situation of graduates is not optimistic, and entrepreneurship has become another choice for College Students. Jumei CEO Chen Ou created the GG game platform during his college years, and sold GG platforms, earning tens of millions of dollars. In 2009, Zhang Xuhao founded the "hungry" online food delivery platform. Successful entrepreneurial cases attract more college students. But it is undeniable that college students are also faced with numerous risks of failure, entrepreneurship is not an easy task. Students lack human capital related to industry experience and lack of social capital to support entrepreneurship.

Many researches are focused on entrepreneur`s peculiarity and the influence of peculiarity on entrepreneurial performance[1]. There is little attention to the influence of human capital and social capital on the entrepreneurial process. Lack of dilemma analysis and countermeasures about human capital and social capital.

\section{THE CONNOTATION OF HUMAN CAPITAL AND SOCIAL} CAPITAL

In entrepreneurship, entrepreneur are at the core of company [2]. Researchers divide human capital into two categories: one is general human capital, and the other is special human capital [3]. In general, general human capital refers to the basic and extensive skills, such as, formal education, work experience; Special human capital can often be regarded as the specific skills, which is accumulated by personal training and personal experience. In other words, it can be understood the ability that the entrepreneur based on previous experience, identifies potential customers and potential things [3]. The scholar Nahapiet and Ghoshal (1998) firstly put forward the theory of social capital. Embedded in network of relationships between individuals or social individuals, obtain the total number of actual and potential resources through the network [4]. These two scholars divided social capital into three basic dimensions: relational dimension, structural dimension and cognitive dimension.

The influence of human capital and social capital in entrepreneurship is mainly reflected in the three stages: identify entrepreneurial opportunities, found enterprise, Enterprise development. Firstly, entrepreneurial opportunity recognition include discovering new opportunities in a complex environment and seizing new opportunities. Zhu Renhong considered the foundation of entrepreneurship is to grasp the opportunities and to integrate resources creatively [5]. Secondly, in the stage of enterprise creation, resources play an important role and the human capital and social capital determine the ability of acquiring resources. Finally, the growth of an enterprise requires the human capital and social capital of the manager to support it. Human capital is the key resource for founding new enterprises, and the highquality human capital can promote the formulation and implementation of enterprise strategy in developing new enterprises. Good strategic decision and executive ability will also promote the benign operation of enterprises, so as to improve the performance of enterprises. Social capital of entrepreneur will influence the ability of enterprise resource acquisition in the process of entrepreneurship. 


\section{THE DILEMMA OF HUMAN CAPITAL AND SOCIAL CAPITAL IN ENTREPRENEURSHIP}

Human capital and social capital will affect entrepreneur for distinguishing opportunities, funding enterprise, managing and developing new enterprise.

\section{A. About human capital}

Schults (1961) consider that human capital is the skills from investing education, training, practical experience, etc. and knowledge accumulation, usually referred to as "no material capital[6]." There three existing problems in human capital:

\section{1) Lack of entrepreneurial knowledge}

Mr. Cheng Siwei, "the godfather of venture capital ",

Consider entrepreneurship four prerequisites: fourdimensional knowledge structure, professional depth, discipline breadth, philosophy height. In addition, they need have a long-term perspective. Nowadays in university education, entrepreneurship education has received little attention. Entrepreneurship courses are more timeliness, many entrepreneurial courses will be out of line with the practice at that time, so that the entrepreneurial knowledge can not meet their entrepreneurial needs.

\section{2) Lack of entrepreneurial qualities}

College students usually lack entrepreneurial practice opportunities, so that they lack of entrepreneurial quality[7]. In addition, college students' ability of risking resistance and anti-frustration is poor, equally post-90s generation, they have weak psychological endurance[8]. When they start an undertaking, they don't have strong psychology, no clearly business goals and firmly volition. Many college students lack of entrepreneurial spirit, such as, hardworking, persistent and dauntless. Even if they have entrepreneurial knowledge, however, lack of entrepreneurial spirit, and ultimately difficult to succeed in business. As a matter of fact, most entrepreneurship education guidance are short of entrepreneurial experience and lack of understanding of entrepreneurship [9]. So they need to further improve their entrepreneurial quality.

\section{3) Lack of Entrepreneurial Practice}

Entrepreneurial knowledge must be applied in practice, only in this way can entrepreneur really understand it. However, it is hard for entrepreneur to realize it from theory to practice. The reasons are that there are no business simulation platform, the entrepreneur just get guidance in class, and most of college students just learn knowledge. However, knowledge is not equal to ability. As we all know that we know the methods to solve problem, but we can't really solve the problem. Mastering the knowledge of entrepreneurship just like the basic of building. The more important things are that the entrepreneur have chances to turn the knowledge of entrepreneurship into the experience and ability of entrepreneurship. College students lack of business simulation platform due to the lack of the experience of entrepreneurship.

\section{B. About Social capital}

Social capital is a multidimensional concept. In other words, social capital has many forms. Upoff (2000) divided social capital into two categories: one is structural social capital, it includes social organization, standard and procedures. The other is the cultural social capital, it refers to standard, values, attitudes, belief, trust, reciprocity and so on[10]. The main difficulties for entrepreneur are that they lack of connections and venture capital.

\section{1) Lack of connections}

Entrepreneurship is not a single activity. It needs to change information with social and others. In order to get range connections, entrepreneurs who has to contact with other people. Meanwhile, entrepreneur can get the experience of entrepreneurship. Get more chances and reduce the risk of failure. What's more, through one connection can develop another connection. It is a good way to establish trust quickly. All in all, entrepreneur can get more chances to succeed... Another question is that college students' connection are limited, because they don't communicate with the society. Their connection are limited to family, classmates and teachers. As we all know, entrepreneurship teams needs all kinds of people who have different knowledge. The common facts are that entrepreneur have the same knowledge in university. Therefore, it is hard for them to deal with problems in entrepreneurship.

\section{2) Lack of entrepreneurial funds}

In the whole process of entrepreneurship, anyone can not avoid to put into start-up capital. Entrepreneur don`t begin to work, so they don`t have enough money. Most of start-up capital come from their parents, relatives and friends. Although, government and financial institutions provide support policy, it not work as we hoped. Because of all kinds of reasons, most of policy funds just as the auxiliary fund... Lack of entrepreneurial funds make it is harder for entrepreneur to succeed... Moreover, lack of funds may make entrepreneur miss the best chances to succeed.

\section{THE COPING STRATEGY OF HUMAN CAPITAL AND SOCIAL CAPITAL IN ENTREPRENEURSHIP}

\section{A. Human capital accumulation}

\section{1) Rich entrepreneurial knowledge}

College students should firstly promote their own entrepreneurial quality. The improvement of entrepreneurial quality requires entrepreneurs to learn a lot of entrepreneurial knowledge, because the knowledge taught by school and entrepreneurial knowledge can not match well. Therefore, they should usually read more business-related books, learn from the success and failure of predecessor. The development of Internet brings new challenges to entrepreneurs, on the one hand, entrepreneurs have no management background, this will certainly cause problems for entrepreneurs to manage and innovate company. On the other hand, this trend cultivate their ability about High-efficiency and analyzing problem. Reading is one of the quickest and effective ways to improve your cognitive ability. 


\section{2) Gain Entrepreneurship experience through} entrepreneurial activities

Entrepreneurs not only need to acquire knowledge, as the founder, entrepreneurs also need to learn entrepreneurial management skills and management experience. More attention must be paid to linking theory with practice, only "Standing on the shoulders of giants" can see farther. This requires university students to actively participate in various entrepreneurial competitions, entrepreneurial team competitions, at the same time, take part in the company internship and have more internship experience. Social practice can reinforce their enterprise consciousness, increase the students' life experience, broaden their horizons, improve their knowledge, accumulate their experience, and ultimately develop their ability of doing pioneering work.

\section{3) Set clear goals to cultivate entrepreneurial quality}

College students' ability of risking resistance and antifrustration is poor. In order to persist in pursuing their goals, it really requires entrepreneurs to set a clear goal for themselves. Entrepreneurs must understands themselves correctly, and choose venture project that seems right for themselves by utilizing own advantages. In this way, college students always have passion when they do pioneering work, even though meet setbacks, not give up halfway.

\section{B. Social capital accumulation}

1) Fully utilize all sorts of network to develop resources The rise of independent start-ups, more business information releasing and service platform on the Internet makes entrepreneurial information exchanging promptly. Through this business platform, not only get information about entrepreneurial projects, but get the opportunity to meet different people who are interested in doing pioneering work. College students entrepreneurs can participate in business conference, interact with different people and find entrepreneurial partners, getting information about business conference form different public platforms, You can broaden your social capital to a great extent, if you try to jump out of own circle.

2) Participate in the community activity to develop human capital

The school community is a kind of social capital in university. The individual students who are interested in entrepreneurship should make the best use of alumni resources and develop their own social capital by making some new friends in the alumni association. Alumni entrepreneurial experience and social status can provide advice or direct help to students who want to do pioneering work. You can also get useful information about entrepreneurship by exchanging ideas from various entrepreneurial societies held by schools. The more you communicate with successful entrepreneurs, the more social capital you can get and increase in value.

3) Gain recognition of the external world with the help of the school teacher

College teachers are also an important source of social capital in the process of College Students' Entrepreneurship, if reasonable use is made of the social capital of teachers. From Bote's theory of structural holes, the connections between members can be interrupted in social networks. The major activities of college students are in campus and seldom connected with the outside world. At this time, college teachers become the link between college students and the outside world. Besides, college teachers usually have contact with enterprises or institutions in scientific research or projects. They have a great deal of good social capital. At the same time, college teachers are rich in social experience, and their knowledge level is higher. Their ability to analyze and obtain information is higher than that of college students. Thus, college teachers can offer advice to college students during their entrepreneurial process, help college students to identify entrepreneurial information accurately, analyze industry information and even provide strategic advice, and so on. In addition, colleges can help students get social capital by improving their reputation and influence. Colleges and universities should strengthen the publicity of external images To improve the influence of the colleges in the society can form a halo effect, and the social recognition of the colleges can be improved. And then the external recognition of school students entrepreneurship is promoted, which is beneficial for students to acquire venture capital of the investors.

\section{4) Make full use of state policy to obtain funds}

Finally, college students should take advantage of the country's support policies for them. In order to alleviate the pressure on college students' employment effectively, the state has introduced more preferential policies to support their entrepreneurship. For college students, the state has relaxed the conditions for the registration of registered capital, narrowed the scope of the business, and reduced the administrative management and tax expenses of the enterprise, given entrepreneurial subsidies and entrepreneurial incentives for the venture project of college students. College students can make full use of these preferential policies to solve the related problems in entrepreneurship.

\section{5) Maintain strong ties and get support}

On this basis, student entrepreneurs should maintain strong relationship with family. They should maintain family strong ties actively, make it a strong backing of entrepreneurship. Members of the family relationship will do their utmost to help students overcome the difficulties encountered in the process of entrepreneurship. Generally speaking, the information obtained from the strong relationship between entrepreneurial will be more accurate and timely, more valuable, so college students should consolidate strong family relationships.

\section{CONCLUSION}

The accumulation of human capital and social capital affects all the processes of entrepreneurship, in which the college students have some deficiencies, because of their own special characteristics. Inevitably, it will be a hindrance in the process of entrepreneurship. In the current wave of entrepreneurial age, college students should strengthen their accumulation of entrepreneurial quality, and participate in entrepreneurial activities to obtain entrepreneurial experience actively, in order to establish the entrepreneurial human capital. Under the new situation, the development of the internet and the introduction of college students' 
entrepreneurship policy have provided a good way for college students to obtain social capital. College students should build their own social networks through the internet and school resources, and make good use of government policies to obtain investment funds, so as to make up for their social capital deficiencies. With the emergency of the entrepreneurship, the improvement of the business environment provides good conditions for college students to start their own businesses. College student entrepreneurs should enhance the chance of success by strengthening the construction of the human capital and social capital continuously.

\section{REFERENCES}

[1] Liu Xingguo, Shen Zhiyu, Zhou Xiaohu, How Social Capital Impact on Private Enterprise Entrepreneur in China. [J]. Management of the Economy, 2009(6): 41-46. (In Chinese)

[2] Ni Xiyun, A study of the behavior process of the post-80s entrepreneurs -- an investigation of 30 entrepreneurs [J]. Scientific and Technological Progress and Countermeasures. 2014(4): 131-137. (In Chinese)
[3] Zhang Wei and Chen Linchun, The influence of entrepreneur's human capital and social capital on entrepreneurial process [J]. Technical Economy. 2009, 28(8): 22-27. (In Chinese)

[4] Nahapiet J, Ghoshal S. Social Capital, Intellectual Capital, and the Organizational Advantage [J]. Academy of Management Review, 1998, 23(2):242-266. (In Chinese)

[5] Zhu Renhong. Frontier theory of entrepreneurship research -- definition, conceptual framework and research boundary [J]. Management Science. 2004, 17(4): 71-77. (In Chinese)

[6] Schultz, T.W. Investment in human capital: Reply [J], American Economic Review, 1961, 51(5): 1035-1039.

[7] Wang Jichun. Discussion on entrepreneurship cultivation of college students based on Entrepreneurial Culture -- Taking LianYunGang universities as an example [J]. China Adult Education. 2015, (22): 7678. (In Chinese)

[8] Ying Yuepeng. Frustration analysis and Frustration prevention education among College Students [J]. Theory Monthly. 2003, (11): $92-$ 94. (In Chinese)

[9] Mu Zhirong. Research on the mode of entrepreneurship education for undergraduates in China [J]. Studies in Higher Education. 2006, (11): 79-84. (In Chinese)

[10] Uphoff N. Understanding social capital: learning from the analysis and experience of participation [M]// Social Capital: A Multifaceted Perspective. Sociological Perspectives on Development series. 2000:215-52 